

\title{
A TONGAN TAPUA IN THE PITT RIVERS MUSEUM: HISTORIOGRAPHICAL NOTES AND CURATORIAL REFLECTIONS
}

\author{
JEREMY COOTE \\ Pitt Rivers Museum, University of Oxford
}

In a recent contribution to this journal about tapua — "polished ivory shrines" of Tongan gods - Fergus Clunie (2013) illustrates and briefly discusses an example in the collections of the University of Oxford's Pitt Rivers Museum (hereafter PRM; see Figs 1 and 2). ${ }^{1}$ Clunie discusses the PRM tapua in the context of the lack of reference to such objects in the early voyage literature, noting how "with the exception of one tenuously provenanced Cook voyage specimen in the Pitt Rivers Museum, tapua were evidently not encountered by 18th century visitors" (Clunie 2013: 165). This "tenuous" provenance is expanded upon in the figure caption, which was compiled by Clunie from information provided in the entry for the object in the PRM's electronic database: "this sperm whale tooth tapua with twisted bast card was initially attributed to New Zealand and bore a Cook voyage provenance when transferred from the Ashmolean Museum to the Pitt Rivers Museum in 1886. The provenance remains unproven, however" (Clunie 2013: 166). ${ }^{2}$

It was not part of Clunie's remit to provide a comprehensive account of the documentation of the tapua in the PRM's collections. Given its potential significance, however, I provide here a fuller account of the information provided in the PRM's records. Moreover, thanks to the recent discovery of a collection of manuscript notebooks and draft catalogues at the Ashmolean, I am also able to add to the historic documentation provided in the current database entry. As will become clear, however, in effect my account comprises a "deconstruction" of the records in order to show how nothing is known about the object's history before its arrival in Oxford at an unknown date. Indeed, this is one of those cases where it would have been easier for all concerned if my curatorial predecessors - at the Ashmolean and the PRM- had not attempted to provide a provenance; for almost everything they recorded about the provenance and history of the tapua should be set aside.

\section{FIRST PHASE_ASHMOLEAN MUSEUM, 1870s-1880s}

In 1884 Edward Evans, underkeeper at the Ashmolean Museum from 1879, was given the task of compiling a comprehensive manuscript catalogue of the Ashmolean's "anthropological" collections in preparation for their transfer to the University Museum, where they were to join the newly arrived 

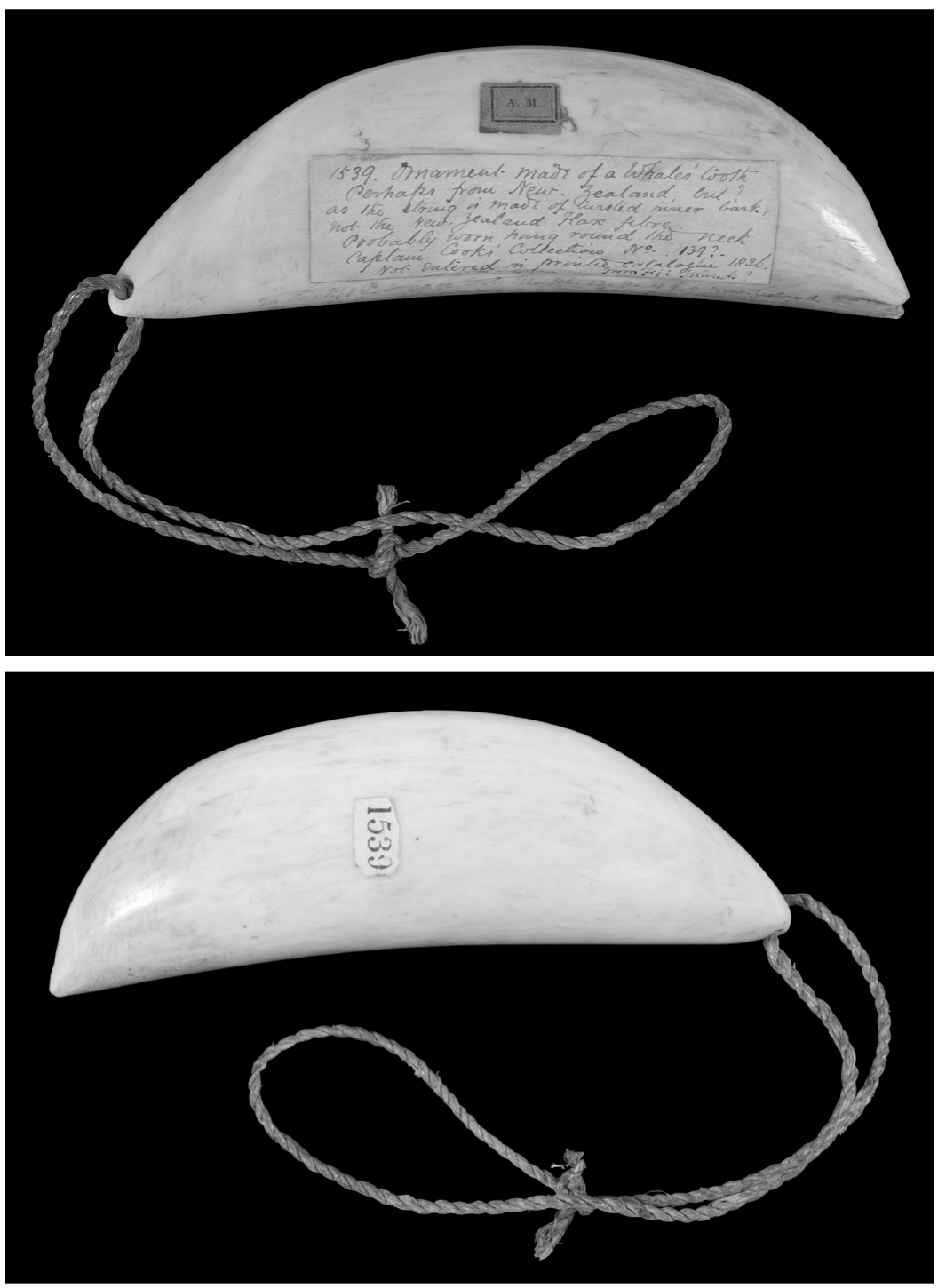

Figures 1 and 2. The tapua in the collections of the PRM (1886.1.1539); sperm whale tooth and hibiscus fibre, $135 \mathrm{~mm}$ long; from a photograph taken for the PRM by Malcolm Osman. Courtesy and copyright, Pitt Rivers Museum, University of Oxford. 
Pitt Rivers Collection (now the PRM). Drawing on the inventories, notes and labels of his predecessor George Augustus Rowell, as well as his own research, Evans compiled a detailed set of catalogue entries in two manuscript volumes preserved at the PRM, ${ }^{3}$ and also prepared detailed labels that he pasted on to the objects themselves. It is not yet clear exactly what Evans's working methods were, but they certainly involved detailed examination of each object, careful checking of the Ashmolean's records, and close reading of some of the relevant voyage and related literature. ${ }^{4}$

It is by no means clear how much credit for Evans's catalogue should be given to Rowell. Evans clearly drew on Rowell's work, but we are a long way from unpicking who was responsible for each piece of information or interpretation. Indeed, since first compiling these "historiographical notes and curatorial reflections" I have been able to trace references to the tapua through the collection of Rowell's and Evans's working notebooks and draft catalogues that were discovered recently at the Ashmolean. I am still some way from fully understanding these, their chronology, and authorship; ${ }^{5}$ and, given their complexity, it may be some time before it proves possible to add the information contained in them to the entries in the PRM's electronic database. Nevertheless, in the interests of completeness, I provide here an account of the entries for the tapua that I have been able to locate.

What appears to be the first and thus "original" entry is in what seems to be Rowell's hand in an undated and untitled soft-bound notebook. It reads:

182 A whale's tooth, reduced in size \& polished, used as an ornament by New Zealanders. It is somewhat of a $\mid$ rounded $\mid$ crescent shape with the concave side rather flat; | at | one point is a small hole, and there has been one at the other, but now broken off. It probably was suspended from the points across the throat. Length $5 \frac{1}{2}$ inches, diameter in the middle $1 \frac{1}{2}$ inch. Capt Cooks collection

The insertions "rounded" and "at" appear to be in the same hand and contemporaneous. The entry contains no evidence for the provenancing of the object to New Zealand or to "Capt Cooks collection".

The second entry is in an undated, leather-bound volume, the front cover of which is tooled "Ashmolean Museum. Polynesian Collection Catalogue No. II Pt. 2"; the title page reads "Ashmolean Museum Catalogue of Articles from Polynesia, New Zealand and Australia Part II". It appears to have begun as a "fair" copy of Rowell's "original" entry, perhaps in the hand of a $\mathrm{Mr}$ Bailey whom, we know from Rowell (see Rowell and Parker 1879: 8), was employed to assist in this work.

182 A whale's tooth, reduced \& [sic] size and polished, used as an ornament by New Zealanders. It is somewhat of a rounded crescent shape with the concave side rather flat; at one point is a small hole, and there has been one 
at the other, but now broken off. It probably was suspended from the points, across the throat. Length $5 \frac{1}{2}$ inches, diameter in the middle [illegible] inch. Captn Cook's Collection. Duncan Catalogue 1836. p. 184. No. 195 (?).

Again, no evidence is provided for the provenancing of the object to New Zealand or to "Capt Cooks collection". Rowell (or conceivably Bailey) has, however, tentatively identified the object as being that listed as No. 195 on page 184 of the "Catalogue, 1836"; that is, the catalogue of the Ashmolean collection compiled by the then keeper Philip Bury Duncan. That entry reads "Shell ornament.-Otaheite" (Ashmolean 1836: 184). It seems unlikely that whale tooth would have been taken for shell, but it has not yet been possible to demonstrate that any surviving object can be definitively associated with that object, so it is at least possible that the tapua was thought in 1836 to match the entry for a shell ornament from Tahiti. ${ }^{6}$

This entry was then amended, by Evans, either at one time or at different moments in time to read:

1539. A whale's tooth, reduced in size and polished, used as an ornament by New Zealanders. It is of a rounded crescent shape form, except that the concave side is rather flatter of the two; at one end is a small hole through which is passed a cord, and there has been a corresponding hole at the other end which is now broken out. It probably was suspended from the ends by the string across the throat or breast. Length $54 / 10$ inches, diameter in the middle $17 / 10$ by $17 / 20$ inch. Captn. Cook's Collection. 1772-74. No (?) Probably not entered in the Duncan Catalogue 1836. Apparently from Tahiti.

Again, no evidence is given for the suggested New Zealand provenance, or for assigning it to "Captn. Cook's Collection", though for the first time the dates of the second voyage are given. Evans has, however, seemingly dismissed the possibility that the 1836 entry for a "Shell ornament.Otaheite" is relevant; although — confusingly — he appears to have accepted the suggestion of a Tahitian provenance.

This entry appears to be what was drawn on by Evans in compiling the fair-copy manuscript catalogue of the Ashmolean's anthropological collection that survives at the PRM. As it stands today (see Fig. 3), it contains a number of inserts and deletions, all of which appear to be in Evans's hand but not all of which are necessarily contemporaneous. Originally, the entry appears to have read as follows: ${ }^{7}$

1539. A Whales' tooth, reduced in size and polished, used as an ornament by New Zealanders. It is rounded on all sides, and nearly of a crescent shaped outline, except that the concave side is rather flatter. At one of the pointed ends is a small hole through which is passed a short string made of twisted 


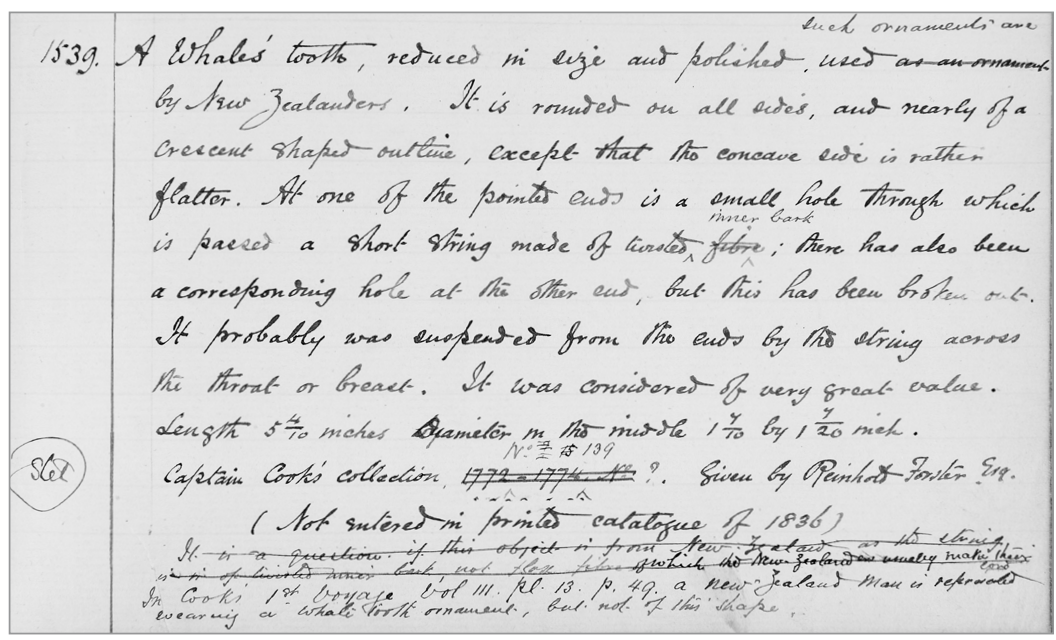

Figure 3. Edward Evans's entry for the tapua on page 257 of volume 2 of the "List of Anthropological Objects Transferred from the Ashmolean to the Pitt Rivers Museum"; PRM, Catalogues; from a photograph taken for the PRM by Malcolm Osman. Courtesy and copyright, Pitt Rivers Museum, University of Oxford.

fibre; there has also been a corresponding hole at the other end, but this has been broken out. It probably was suspended from the ends by the string across the throat or breast. It was considered of very great value. Length $54 / 10$ inches Diameter in the middle 17/10 by 17/20 inch. Captain Cook's collection, 1772-1774. No. ?. Given by Reinhold Forster, Esq. (Not entered in printed catalogue of 1836)

Having compiled the entry, Evans seems to have had a number of second thoughts. Most interestingly, he expresses doubts as to the tooth's New Zealand provenance, appending below the original entry:

It is a question if this object is from New Zealand as the string is of twisted inner bark, not flax fibre of which the New Zealanders usually make their cord.

By this stage in the project, apparently, Evans had come to know-from his reading and from the objects he had already catalogued - that "New Zealanders" generally used flax (i.e., harakeke; Phormium tenax, New Zealand flax) to produce fibre ( $m u k a)$ to make their cord. It was apparently at this moment in Evans's "engagement" with the tooth that he wrote the label that remains affixed to it (Fig. 4): 
1539. Ornament made of a Whales' tooth. Perhaps from New Zealand, but? as the string is made of twisted inner bark, not the New Zealand flax fibre. Probably worn hung round the neck. Captain Cook's Collection No. 139? Not entered in printed catalogue 1836 .

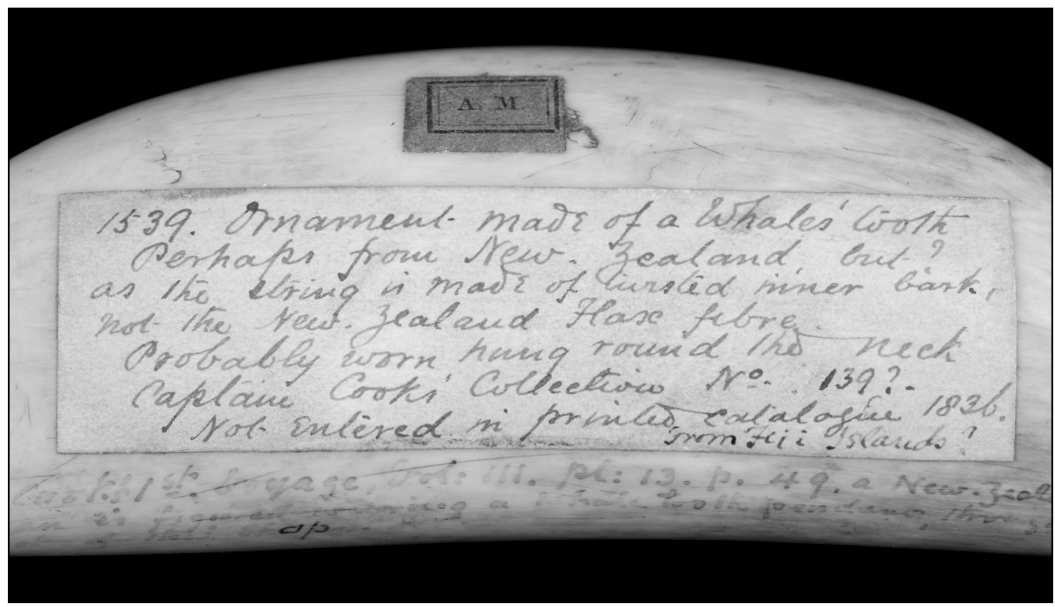

Figure 4. Close-up of the label on the tapua in the collections of the PRM (1886.1.1539); from a photograph taken for the PRM by Malcolm Osman. Courtesy and copyright, Pitt Rivers Museum, University of Oxford.

The number "139" with its question mark may have been added later (it is difficult to tell), but it appears to have been written at the same time as the main part of the label.

Evans then appears to overcome his doubts about the New Zealand provenance. He strikes through the words he had added to the catalogue entry: "It is a question if this object is from New Zealand as the string is of twisted inner bark, not flax fibre of which the New Zealanders usually make their cord") and adds: "In Cook's 1st Voyage Vol III. pl. 13. p. 49. a New Zealand man is represented wearing a whale tooth ornament, but not of this shape." Presumably at the same time, he adds almost identical wording to the surface of the tooth, below the label (Fig. 5): "In Cook's 1st voyage, vol. iii. pl. 13. p. 49, a New Zealand man is figured wearing a whale tooth ornament, though not of this shape."

As will be appreciated, Evans's description of the physical characteristics of the tapua is detailed and accurate. Both his provenancing of the tooth 


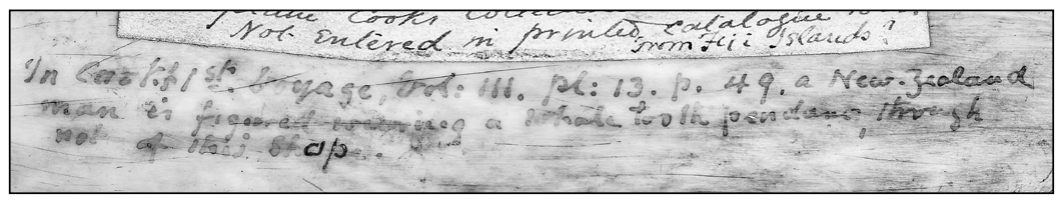

Figure 5. Close-up of the inscription below the label on the tapua in the collections of the PRM (1886.1.1539); from a photograph taken for the PRM by Malcolm Osman. Courtesy and copyright, Pitt Rivers Museum, University of Oxford.

to New Zealand and his assertion that it forms part of "Captain Cook's Collection.... Given by Reinhold Forster, Esq.", however, warrant close attention. I take the provenancing to New Zealand first.

Given his final comment-“'In Cook's 1st Voyage Vol. III, pl. 13. p. 49. a New Zealand man is represented wearing a whale tooth ornament, but not of this shape"-it would appear that it is on the basis of this image that Evans provenances the tooth to New Zealand. The reference, of course, is to the famous plate of "The head of New Zealander, with a comb in his hair, an ornament of green stone in his ear, and another of a fish's tooth round his neck" in John Hawkesworth's Account of the Voyages (Fig. 6) ${ }^{8}$ Truth be told, the "fish's tooth" in the illustration - a Māori rei puta-bears little resemblance to the tapua. Apparently, however, Evans's identification of the tooth as a Māori ornament did not depend on the illustration, or at least not on the illustration alone. For in his manuscript "Notes from Captain Cook's Voyages", Evans draws on the following passage in Hawkesworth to note "|Seals and| Sea-lions' teeth fashioned into an ornament like a bodkin and worn by the natives at their breast, and highly valued": 9

... there are indeed seals upon the coast, and we once saw a sea lion, but we imagine they are seldom caught, for though we saw some of their teeth which were fashioned into an ornament like a bodkin and worn by the natives at their breast, and highly valued, we saw none of their skins. (Hawkesworth 1773 [III]: 34)

Here presumably is the authority for Evans's words "used as an ornament by New Zealanders" (later amended to "such ornaments are used by New Zealanders", presumably to reflect the doubt that had crept in as to the object's provenance) and for his "It was considered of very great value", a comment that does not appear in the earlier entries. Clearly, the "fish's tooth" in the illustration in Hawkesworth has a different shape to that of the tapua - it is, as Evans notes, "not of this shape"; moreover, it has three holes at one end, 


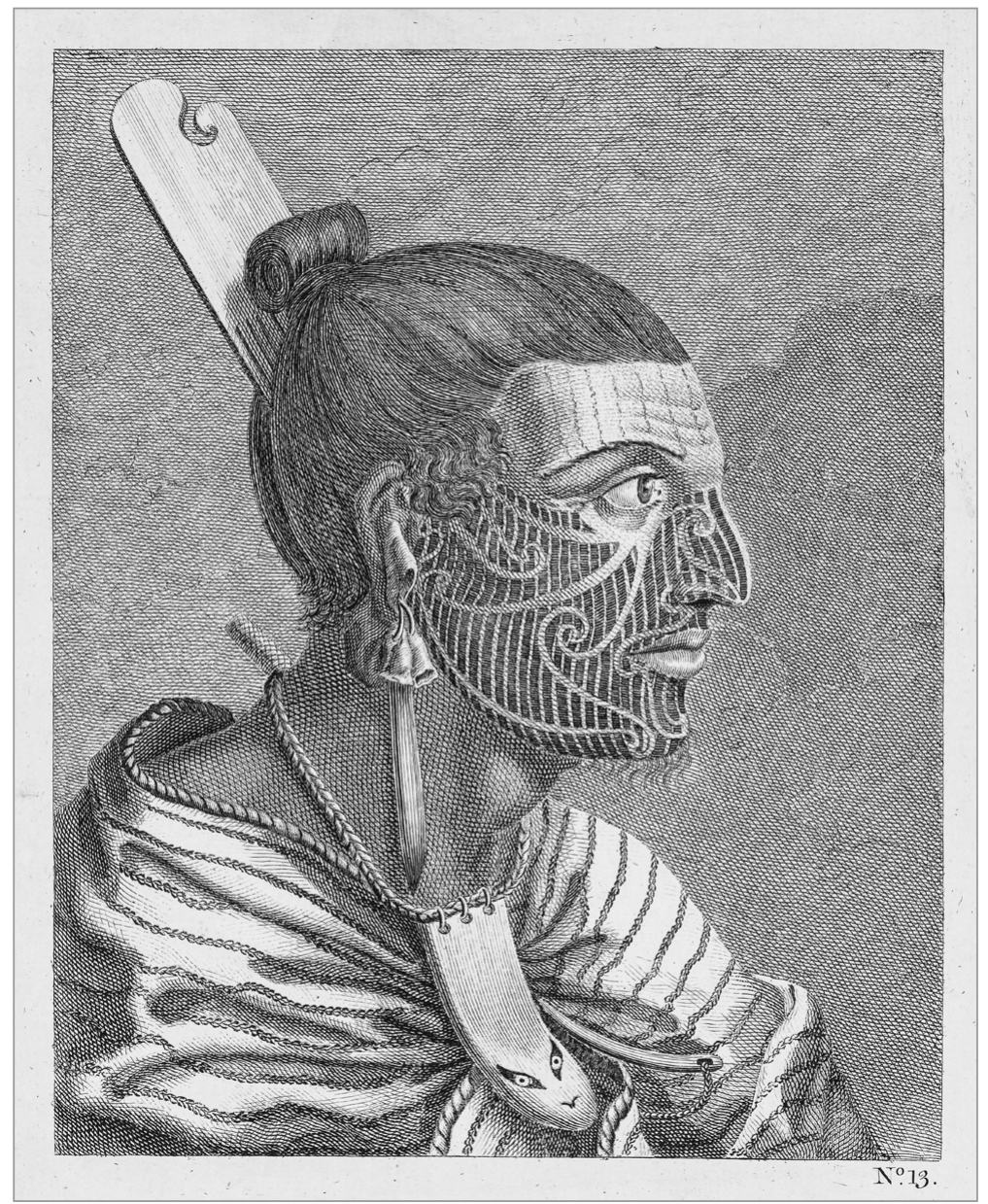

Figure 6. The head of a New Zealander, with a comb in his hair, an ornament of green stone in his ear, and another of a fish's tooth round his neck. From a copy in the Bodleian Library, University of Oxford (shelfmark 900 s. 5 [v. 3]), of the second edition of Hawkesworth's An Account of the Voyages Undertaken by the Order of His Present Majesty for Making Discoveries in the Southern Hemisphere... (London, 1773) (see Hawkesworth 1773 [III]: plate 13, facing page 49). Copyright, Bodleian Library, University of Oxford 
rather than the single hole at either end. Evans thus reasonably concludes, as Rowell had before him: "It probably was suspended from the ends by the string across the throat or breast. It was considered of very great value."

What is puzzling is that, taken together, the reference and image in Hawkesworth seem to have been regarded by Evans as sufficient to overcome the negative evidence provided by the fact that the cord is not made of flax fibre and that the tooth in the image and the tooth he was cataloguing look very different. As Clunie notes, however: "tapua were evidently not encountered by 18th-century visitors" to Tonga. Thus, Evans's readings of the Cook-voyage literature could not be expected to lead him to any other conclusion. Convinced, as he was, that the tooth was part of "Captain Cook's collection.... Given by Reinhold Forster, Esq." he was quite reasonably led to the conclusion that the tooth was a Māori ornament. Altogether, therefore, it is unsurprising that Evans concluded that the object was from New Zealand.

Evans appears to have been convinced that the tooth was from "Captain Cook's collection". By this he meant that it was from the Cook-voyage collection, then at the Ashmolean, commonly known as the Forster Collection; that is, the collection given to the University of Oxford by Johann Reinhold Forster and his son Johann George Adam Forster in 1776 soon after returning from accompanying Cook on the Resolution on his second famous voyage of 1772-1775. Evans knew very well that the collection came from Forster, but knew little about him. Evans also knew that what he called "Captain Cook's collection" was numbered. He had already come across objects bearing small paper labels bearing numbers. The tooth did not bear such a label at the time Evans catalogued it, but he seems to have assumed that it had borne such a label in the past and for a moment to have made an educated guess that it was numbered " 15 " or a three-figure number beginning " $15 . .$. ". This suggestion was deleted, however, and the alternative suggestion made that it was number "139". We know from the next entry in Evans's catalogue that a label bearing the number " 139 " had come off an object and that it was not clear from which object it had come. ${ }^{10}$ Evans thought it might have come off the tooth, but also considered the possibility that it had come off the object given the Ashmolean number "1540" (now PRM object 1886.1.1540), which we now know to be the case.

What Evans did not know was that these numbered labels had been affixed to the objects by the Forsters and that they referred to a numbered list entitled "Catalogue of Curiosities sent to Oxford" that the Forsters supplied when they gave the collection to the University in January 1776 (see, for example, Coote et al. 2000). For some reason, by the time Evans was working on the collection the list had been mislaid (it was not to be "rediscovered" and made use of until 1969; see below). If Evans had had access to the list, he would 
have seen that No. 139 was bracketed by the Forsters with No. 140, referring to two ornaments from the Marquesas Islands (which survive at the PRM as 1886.1.1540 and 1886.1.1541); and he would also have seen that there was no entry in the Forster list that could be interpreted as referring to the tooth.

It is not clear why Evans was seemingly convinced that the tooth was part of "Captain Cook's collection". He does not record the presence of any other label, and duly notes that the tooth does not appear to have been included in the Ashmolean's catalogue of 1836, where at least some of "Captain Cook's collection" was listed. One is inclined to wonder if it was merely as a result of his close reading of Hawkesworth that he determined that the tooth had been collected on Cook's voyages. Without the discovery of further documentary evidence, it is unlikely that we will ever know for sure quite why Evans came to the conclusions he did. What is clear now is that the evidence he used was spurious, that the tooth is certainly not Māori work, and that there is no reason whatsoever to believe that it was collected on one of Cook's voyages. ${ }^{11}$

Finally, Evans himself seems to have had second, or third or fourth, thoughts. At the very bottom of the label on the object (Fig. 4), in what is clearly Evans's hand, are the words "From Fiji Islands?". The tapua is known to have been physically transferred from the Ashmolean to the University Museum on 19 April 1886, so Evans must have added this tentative provenance before then. What he had read or seen - in a publication or "in the flesh" - that led him to this possibility is not known. A tabua was to arrive in Oxford in the summer of 1885 as part of the Pitt Rivers Collection (1884.74.8), but given how long it took for the collection to be unpacked and displayed (see Petch 2007), it seems unlikely that he saw it, but perhaps he did-or perhaps someone else suggested the provenance to him. Of course, there could have been examples in private collections in Oxford, including that of Henry Nottidge Moseley, Linacre Professor of Human and Comparative Anatomy at Oxford from 1881, who had served as naturalist on the Challenger expedition of 1876 and had made collections in Fiji. ${ }^{12}$ Unfortunately, for the next 111 years, the PRM's documentation of the object was founded not on what was written on the label on the object but on what was written in the entry in Evans's catalogue, to which he did not add the tentative Fijian provenance.

\section{SECOND PHASE—PITT RIVERS MUSEUM, 1944-2014}

Subsequent attempts by the curatorial staff of the PRM to catalogue the tooth were bedevilled by two problems: the continuing lack of access to the Forsters' list and the fact that repeated entries were made for the tooth without it being seen. If it had been seen, my predecessors would surely have recognised its similarity to Fijian tabua; and, if they did not, Evans's words 'From Fiji Islands?' should have led them in that direction. 
Thus, when in the summer of 1944 the then Curator of the PRM, T.K. Penniman, produced a brief-entry version of Evans's catalogue to serve as a retrospective accessions register for the material that had been transferred from the Ashmolean in 1886, his entry took the following form (Fig. 7): ${ }^{13}$

1539. ?NEW ZEALAND, ?MAORI. Pared \& polished whale's tooth, fat crescent shape, round section, hole at each end, one broken, and fibre cord in one hole. ?Aurei, i.e, ornament for fastening cloak. Not seen. Capt. Cook coll. no. 139. Reinhold Forster.

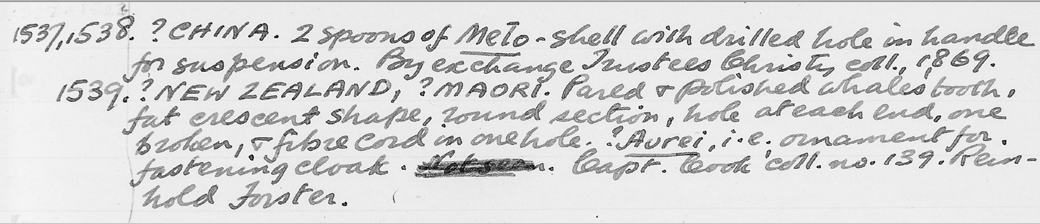

Figure 7. T.K. Penniman's entry for the tapua in the retrospectively compiled accessions register for the objects transferred from the Ashmolean to the PRM in the 1880s; from a photograph taken for the PRM by Malcolm Osman. Courtesy and copyright, Pitt Rivers Museum, University of Oxford.

As can be seen, Penniman follows Evans's description and his tentative provenance. Drawing on his own knowledge, he also suggests that it might be a bodkin or aurei. This entry, in turn, was copied more or less verbatim when, also in 1944, entries for the object were drawn up on cards for inclusion in the "geographical/cultural" and "typological" card indexes. On the relevant cards - filed respectively under "Polynesia, New Zealand, Unlocalized, Ornaments, Aurei" and "Clothing, Accessories, Fastenings, Oceania, Polynesia, New Zealand Maori”- - the tooth was detailed as follows (Fig. 8):

Ashmole 131 Capt. Cook ?NEW ZEALAND ?MAORI A.M. 1539. Pared and polished whale's tooth, fat crescent shape, round section, hole at each end, one broken, and fibre cord in one hole. ?Aurei, i.e. ornament for fastening cloak. Not seen. Capt. Cook coll. 139. Reinhold Forster.

Māori specialists will be surprised by the suggestion that such a large tooth might have been thought to be an aurei or cloak fastener, but it is clear from all these entries that at the time they were composed the tooth had not been seen (though the dimensions recorded by Evans should perhaps have been enough to make it clear that the tooth was far too big to be an aurei). 


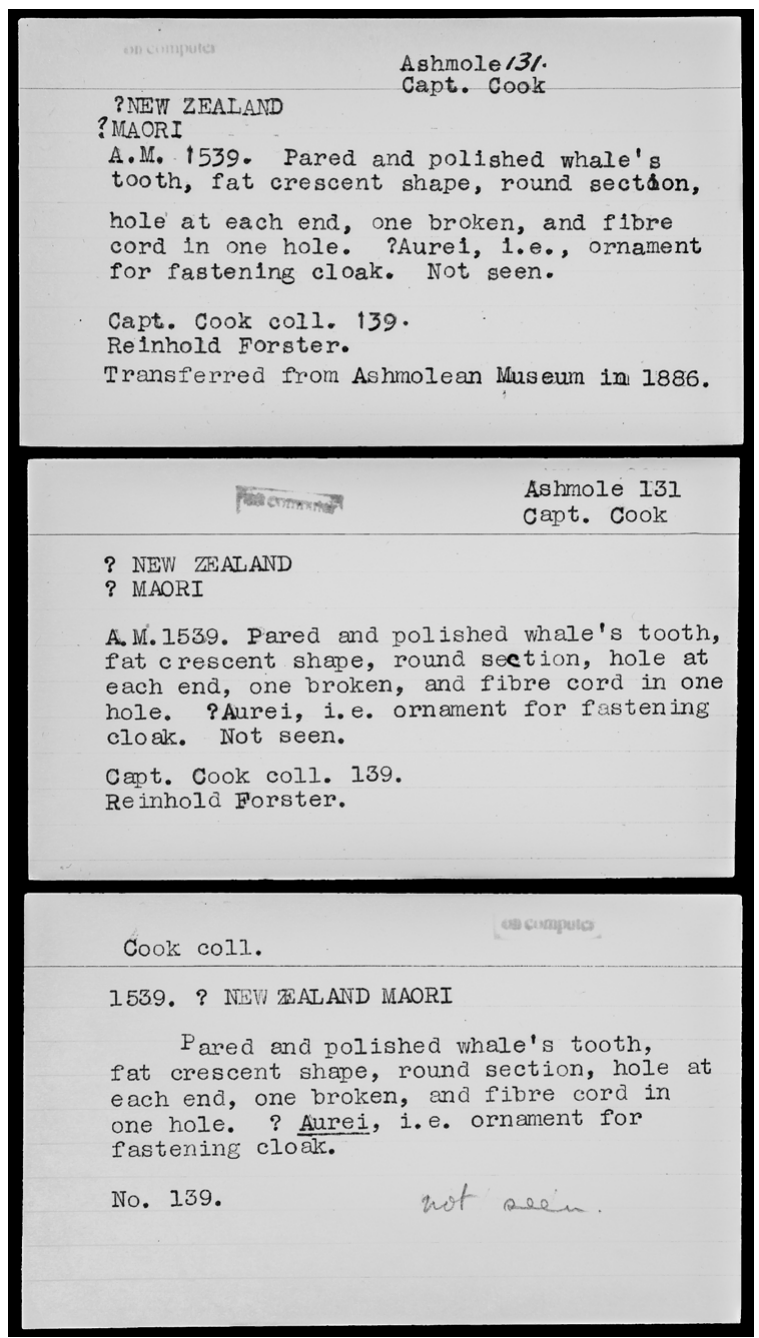

Figure 8. Three cards from the PRM's card index system bearing information about the tapua (top, the card from the geographically/culturally filed drawers; middle, the card from the typologically filed drawers; bottom, the "Cook-collection" card); from a photograph taken for the PRM by Malcolm Osman. Courtesy and copyright, Pitt Rivers Museum, University of Oxford. 
Virtually the same information was also recorded on an index card in the "Ornaments" section of the special "Capt. Cook Collection By Subjects" drawer, compiled by Penniman's colleague Beatrice Blackwood in 1955-56 (see Penniman 1957: 656; Fig. 8):

Cook coll. 1539. ? NEW ZEALAND MAORI Pared and polished whale's tooth, fat crescent shape, round section, hole at each end, one broken, and fibre cord in one hole. ? Aurei, i.e. ornament for fastening cloak. No. 139. [Added in pencil: "not seen".]

From the time of its transfer in 1886, therefore, the tooth was recorded as (possibly) Māori and, from 1944, as (possibly) an aurei or clothes fastener. So matters stood until the late 1960s when Peter Gathercole, newly appointed lecturer in ethnology at the PRM, set about researching the Forster Collection for a special exhibition. ${ }^{14}$ Gathercole was not yet an expert on Polynesian material culture, but he knew enough to be able to dismiss the idea that the tooth was Māori. No doubt the newly discovered "Catalogue of Curiosities sent to Oxford" was carefully consulted, just in case there was an entry that could be taken to refer to a tabua-like object. ${ }^{15}$ Finding that there was not, and presumably after consulting with Adrienne Kaeppler, who in 1968 had made a thorough study of the Tongan objects in the Forster Collection (see Kaeppler 1971), Gathercole concluded that the tooth was not from the Forster Collection, and thus not from Cook's voyages.

When in March 1997 he worked with Nicolette Meister and the present author on a project to improve and enhance the documentation of the Forster Collection (see Coote et al. 1999), Gathercole confirmed his earlier conclusion. It was at this stage that an entry for the tooth was first created in the PRM's electronic database. As part of this process, all previous references to the tooth in the PRM's records were transcribed into the entry. Importantly, Evans's label was also transcribed. At this point, for the first time, his tentative suggestion of a Fijian provenance- - "From Fiji Islands?"-was recorded. Confirmed by Gathercole, "Fiji" became the provenance recorded in the database.

So matters stood until the tooth was examined by Steven Hooper in December 2011 and Clunie himself in July 2013. The provenancing of the tooth to Fiji meant that its database entry was one of those retrieved by Hooper in preparation for one of his research trips to the PRM as part of the "Fijian Arts" project, for which the PRM was a project partner. ${ }^{16}$ On examining it in December 2011 he identified it as a Fijian tabua and suggested that the cord was not coir as had previously been recorded in the database entry, but "reddened hibiscus", 17 he also suggested that it was "likely to be early 19th century". Following up Hooper's visit, Clunie identified it as a Tongan tapua, noting "It is small and those tend to be oldest". Soon after, of course, Hooper 
and Clunie completed work on their pair of complementary articles on Fijian and Tongan whale teeth published in the JPS (Clunie 2013, Hooper 2013).

\section{OTHER POSSIBLE HISTORIES}

So where does this leave things? I have no reason to disagree with Clunie's identification of the object as a Tongan tapua, nor with his suggestion that it is "old". However, it is clear that there is absolutely no reason to reiterate a possible Cook-voyage provenance. Indeed, the suggestion of a Cook-voyage provenance has no firmer basis than does the suggestion that the tapua is a Māori cloak-fastener! It is important for the PRM to continue to include Evans's notes and all later records in its electronic database entry, but it is also important that future researchers are not seduced by the name "Cook". That it was once suggested, or believed even, that the tapua was part of the Forster Cook-voyage collection is part of the tapua's history, but a part that needs to be properly understood. Museum curators and collections-oriented researchers quite understandably get excited at the prospect of making interesting discoveries, such as identifying objects that were collected on Cook's voyages. I have done so myself, as reported in these pages recently (see Coote and Uden 2013). It is rather less exciting demonstrating that an object was not collected on one of Cook's voyages, though this may be no less important an outcome.

As for when it was collected, where, and by whom we know nothing. It may have arrived at the Ashmolean as part of an identifiable collection or as a single-item donation - but we may never know who gave it or when. This is, of course, a disappointing situation; especially when compared with the situation at the PRM's "sister" museum in Cambridge, the Museum of Archaeology and Anthropology (MAA), where a tapua in its collection (Z 5887) is extraordinarily well documented (see Clunie 2013: 192-94, Clunie 2014). Not only is it known who collected the tapua in Cambridge, where, and when - Quaker Daniel Wheeler at a Wesleyan gathering on the Tongan island of Lifuka in 1836 - but it is also known with which god it is associated-Aloalo, the weather and fertility god of the Tongan island groups of Ha 'apai and Vava' $u$. It seems unlikely that it will ever be known who collected the tapua in the PRM's collections, where and when, or with which god it was associated; it will probably remain one of those that, as Clunie movingly puts it, "lie in unmarked graves in Fijian collections" (Clunie 2013: 161). However, the chances of making progress in establishing a provenance are increased immeasurably by setting aside the supposed, tenuous, Cook-voyage provenance; at least, we now know we need to look elsewhere for clues to its history.

It seems most likely that it was "collected" by a missionary, so it may be that a key piece of evidence lies in a missionary account or unpublished 
correspondence. Starting at the other end, however, as I am most qualified to do, with the records in Oxford, there are three ex-Ashmolean, now-PRM collections that stand out as possible sources for the tapua: a collection of Pacific and Alaskan material from the voyage of HMS Blossom (1825-1828), donated in the late 1820 s or early 1830 s; a collection of Fijian material, purchased in 1867; and a collection of general "ethnographic" material, purchased in 1878. All three collections are worthy of further investigation, though all I am able to do here is raise them-in chronological order-as possible sources for the tариа and invite further research.

Beechey Collection from HMS Blossom (1825-1828)

The collection from the voyage of HMS Blossom (1825-1828) was given to the Ashmolean by the voyage commander Frederick William Beechey (17961856), but seemingly without documentation, or at least none that survives. It is not known when Beechey donated the collection, but it must have been before 1836 when a number of items from the collection were listed in the printed catalogue of that date (Ashmolean 1836: $183 \mathrm{ff}$.). The Polynesian portion of the collection has not yet been studied in any detail ${ }^{18}$ though a kava bowl (1886.1.1366) made in Ra'ivavae but apparently acquired by Beechey in Tahiti in March/April 1826 has been published recently (Hooper 2006: 209, cat. 175; Richards 2012: 132, fig. xix; Whitby n.d. [2012]: 61), as has a coconut fibre helmet (1886.1.1529) of uncertain provenance (Richards 2012: 203, fig. 4). The helmet is similar to examples in the collections of the Bishop Museum (C2848 and C2849), provenanced by Te Rangi Hiroa (1944: 83-86) to the Cook Islands. Like other objects in the Beechey Collection this bears a label, said by Evans to be in Beechey's hand, identifying it as Tongan: "War Helmet of Tongataboo. Friendly Islands". There are also two clubs said to be from Tonga, one of which (1886.1.1499), once bore a label in Beechey's hand reading "Club of Tongataboo Friendly Islands", and a spear (1886.1.1511) bearing a label, again said to be in Beechey's hand, reading "Spear of Tongataboo presented by Captain Beechey". The Blossom did not visit Tonga on its voyage of 1825-1828 (Beechey 1831). However, it appears that Beechey acquired a number of pieces from locations other than where they were made, so it must be at least possible that Beechey acquired the tapua in Tahiti, or somewhere else in the Pacific, and gave it to the Ashmolean.

\section{"Figi" Collection (Purchased 1867)}

In 1867 the Ashmolean purchased a collection of Fijian material that, according to surviving documentation, had been collected "at the Figi or Cannibal Islands by an old Resident among the Savages". The collection was accompanied by a three-page handwritten list that was pasted into the 
Ashmolean's letter-book. There is no reference in the list to anything that could conceivably be a tapua.$^{19}$ However, it is quite possible that the list was not comprehensive and that the tapua was an unlisted part of the collection.

\section{Ramsden Collection (Purchased 1878)}

In 1878 the Ashmolean purchased the "Ramsden Collection", comprising some 270 ethnographic objects. ${ }^{20}$ Little work has been done on the Ramsden collection and little is known about it. The collection appears to have been formed by Robert Ramsden (1784-1865) and/or his grandson Robert Henry Ramsden (1845-1874) of Carlton Hall, Carlton-in-Lindrick, near Worksop in Nottinghamshire. There are around 100 Pacific pieces in the collection at the PRM, 70 of which are from Polynesia, of which ten or so are from Tonga. The majority of the objects identified as being from Tonga are clubs, though there is also a barkcloth printing tablet (1886.1.1679) and a wooden bucket covered with coconut-fibre and shell beads (1886.1.1331). The Ramsden Collection was shuffled back and forth between the Ashmolean, the University Museum and (eventually) the Pitt Rivers in the 1880s, and some documentation may have been lost. It is thus possible that the tapua formed part of the collection, though — as with the Beechey and "Figi" collections - there is no evidence that it did.

$$
* * *
$$

Some readers may wonder at the point of devoting some 8,000 words to demonstrating how little is known about the history and provenance of a single Polynesian object held in a museum collection on the other side of the world. The important point, surely, is that - thanks to Clunie — the object is now identified as a Tongan tapua. That is certainly how it is now described in the PRM's database, where full details of Clunie's article and a summary of his account of tapua in general are given. Of course, Evans's suggestionfollowed by Penniman and his colleagues at the PRM - that it is a Māori ornament continues to have its place in the museum's electronic database entry, as does the re-provenancing of the object to Fiji-tentatively by Evans on the object's label and later by Gathercole and, subsequently, Hooper. ${ }^{21}$ Moreover, when this article is published a reference to it and a summary of its argument will be added to the entry. Just as the scattered references to tapua in the missionary and related literature require the exegesis of a 21 st-century expert, so the inscriptions, labels and catalogue entries of 19th-century underkeepers need the exegesis of a 21 st-century curator. Paradoxically, it seems that all these words are needed to free the object from its apparently rich but in fact impoverished documentation. 
As already mentioned, in 1996-1997 the entries in Evans's catalogue relating to known or possible Cook-voyage objects were transcribed into the PRM's computerised database by Nicolette Meister. All other relevant information held by the PRM was reviewed by Gathercole, Meister and myself and then added, suitably annotated, to the database. Thus, on 14 March 1997 the Māori provenance was set aside in favour of Fiji:

According to Peter Gathercole this ornament is definitely not from New Zealand, but is most likely from Fiji. Peter also stated that this ornament is not part of the Forster collection from Cook's 2nd voyage, and probably could not be associated with any of Cook's voyages. ${ }^{22}$

I had thought that this statement would be enough to divert later researchers from focusing on the formerly asserted Cook-voyage provenance that lingers in the database entry. I am, however, grateful to Clunie for highlighting it; in doing so he has provoked me into investigating and reflecting on the process by which Evans arrived at his entry for the tapua and the texts that he wrote on the label and on the object itself. There are some 2,800 entries in Evans's catalogue, relating to some 3,700 objects, of which some 450 are provenanced to Polynesia. They may not all require as much exegesis as that given here, but there is certainly no shortage of work to be done to make the PRM's records for its early collections - including those from Polynesia - as useful and transparent as possible.

\section{ACKNOWLEDGEMENTS}

I am grateful to my PRM colleagues Madeleine Ding, Andrew Hughes, Malcolm Osman and Jeremy Uden for their help in documenting and photographing the tapua, and to Alison Roberts for providing me with access to the recently discovered notebooks and draft catalogues at the Ashmolean Museum. In preparing this account, I have drawn on earlier work on the Forster Collection and its history that was made possible by a series of grants from the Hulme University Fund (1995), the South Eastern Museums Service (1996), the Jerwood/MGC Cataloguing Grants Scheme 1997-1998 (supported by the Museums \& Galleries Commission, the Jerwood Foundation, and the Department for Culture, Media and Sport), and the Innovation Awards Scheme of the Arts and Humanities Research Board (2001; award number B/IA/AN4817/APN13726). Much of this work was carried out with former PRM colleagues Nicolette Meister and Jenny Peck, and with the late Peter Gathercole. I have also drawn on work carried out by my colleague Alison Petch for the "Scoping" project (see note 5), funded by a grant from the John Fell Fund (2012-2013). I am grateful to Steven Hooper for his advice and suggestions, to Fergus Clunie for drawing the PRM tapua to scholarly attention and for his suggestions, and to two anonymous reviewers for their comments. 


\section{NOTES}

1. For authoritative accounts of Tongan tapua and related Fijian tabua, including those of the tabuabuli form that are physically indistinguishable from Tongan tapua, see the paired articles by Fergus Clunie and Steven Hooper in the June 2013 issue of the JPS. For useful summary accounts, see Clunie 2014, Hooper 2014. As will become clear, my concern is with the later history of this particular object and its documentation, rather than its original status and significance, further discussion of which I leave to Clunie and other regional specialists.

2. For the online version of the PRM's fully searchable, regularly updated and increasingly illustrated database, go to $<$ http://objects.prm.ox.ac.uk $>$. The entry for the present object may be accessed directly at $<$ http://objects.prm.ox.ac.uk/ pages/PRMUID25910.html>.

3. "List of Anthropological Objects Transferred from the Ashmolean to the Pitt Rivers' Museum" (2 vols) (compiled by Edward Evans, 1884-1886); University of Oxford, Pitt Rivers Museum, Catalogues. For a transcription, see MacGregor 2000: 255-413.

4. Evans's catalogue entries include frequent reference to relevant passages in the voyage literature and comparative examples in other, published collections. For example, his entries for Polynesian objects include references to William Ellis's Polynesian Researches (see for example, Ellis 1829), J.G. Wood's The Natural History of Man (see Wood 1868) and the catalogue of the Mayer Collection (Gatty 1879-1882). It is not known how much Evans might have drawn from Rowell's earlier work, but Evans's own notes on his reading of "Cook's voyages" survive at the PRM (see note 9).

5. For brief discussions of the work of Evans and his controversial predecessor Rowell, see Ovenell 1986: 230 ff., MacGregor 2000: 255. A full account would need to deal with the newly discovered notebooks and manuscript catalogues (Antiquities, AMS 52), the extensive contemporary correspondence-some of which was privately printed (see for example, Rowell and Parker 1879), and the papers of the late R.F. Ovenell, author of a history of the Ashmolean (University of Oxford, Ashmolean Museum, Department of Antiquities, Archives of Ashmolean Staff Members). For further details, transcriptions of key texts, etc., go to $<\mathrm{http}$ ://web.prm.ox.ac.uk/sma/>, the website of the project "The Invention of Museum Anthropology, 1850-1920: Scoping the Local Material Resources for an Intellectual History of a Global Discipline", and follow the links.

6. It seems more likely that the entry refers to one of the two Marquesan ornaments made from shell in imitation of whale tooth in the Forster collection from Cook's second voyage (Forster 139, 140; 1886.1.1540, 1886.1.1541).

7. As note 3, Vol. 2, p. 257; MacGregor 2000: 399.

8. I have yet to establish whether the particular copy of "Cook's Voyages" Evans consulted can be identified. Given that he gives the reference to the image as "p. 49", however, we can deduce that he was using a copy of the second edition (Hawkesworth 1773; see Beddie 1970: 122, item 650) in which each volume had its own pagination. The image published in Hawkesworth is from an engraving, 
based on a version ascribed to John James Barralet, of Sydney Parkinson's penand-wash drawing Portrait of a New Zeland Man (thought to be Te Kuukuu, the son of a chief of the Bay of Islands); see Joppien and Smith 1985: 184-85, cat. nos 1.125-1.127A.

9. Edward Evans, "Notes from Captain Cook's Three Voyages", circa 1886, 31 pp.; University of Oxford, Pitt Rivers Museum, Manuscript Collections, Pitt Rivers Museum Papers, Box 3, Item 3, folio 9.

10. As note 3, Vol. 2, p. 259; see the record for 1886.1 .1540 at $<$ http://objects.prm. ox.ac.uk/pages/PRMUID25911.html>.

11. Evans was also led by his work on the tapua to suggest that what we now know to be an Inuit tobacco-box in the Beechey collection (1886.1.716) might be a Māori ornament; as note 3, Vol. 1, p. 216, Vol. 2, opp. p. 259. There is not room here to enter any further into this intriguing documentary cul-de-sac.

12. Surprisingly little attention has yet been given to the collections made on the Challenger voyage; for a brief account, see Coote 2015.

13. "Objects transferred from the Ashmolean Museum to the Pitt Rivers Museum in 1886 or later"; University of Oxford, Pitt Rivers Museum, Catalogues, Collections I. Note that this register was compiled from Evans's manuscript catalogue and not from an examination of the objects themselves, though it seems that many of the entries were in due course also checked against the objects, except where they could not be found at the time- -hence, in this case, "Not seen".

14. For an account of the background to the exhibition, see Coote 2005.

15. For the finder's account of the rediscovery of the Forsters' manuscript, see Kaeppler 1972; see also Coote et al. 2000.

16. For information about "Fijian Art: Political Power, Sacred Value, Social Transformation and Collecting Since the 18th Century", visit the project website at $<$ http://www.fijianart.sru.uea.ac.uk $>$.

17. Following microscopic examination, my colleague Jeremy Uden confirms that the fibre cord is made of hibiscus.

18. The Alaskan material has been published; see Bockstoce 1977.

19. "Catalogue of Curiosities and Very Old Carved War Clubs \&c \&c Col[1]ected at the Figi or Cannibal Islands by an old Resident among the Savages" (compiled 1867); University of Oxford, Ashmolean Museum, AMS 16(1). For a transcription, see MacGregor 2000: 253. The identity of the donor of the collection remains unknown and the collection unpublished.

20. The Ramdsen Collection has received little attention within the Museum or elsewhere, and as a result little is known about it. The collection appears to have been numbered and perhaps to have been accompanied by a list. The individual objects in the collection were catalogued by Evans. In addition, a separate manuscript catalogue is held at the PRM: "Ramsden coll. Bought by Ashmolean in 1878. Transferred to Pitt Rivers Museum 1886 - "; University of Oxford, Pitt Rivers Museum, Catalogues, Collections VIII. The PRM also holds a photocopy of another manuscript "Catalogue", kindly supplied by Hermione Waterfield in October 2005, though it is not yet clear how it relates to the collection held at the PRM. Steven Hooper tells me that some objects from the Ramsden Family 
Collection were sold at Christies in March 1972 and that he has heard that there may be a catalogue of the collection in private hands. There is also a collection of Ramdsen family papers in the Nottinghamshire Archives (DD/2500, "Ramsden Family of Carlton in Lindrick"). In other words, there is a lot of work to be done.

21. As previously indicated, it is not obvious to me how or when it will be possible to incorporate into the PRM's database all the entries in the recently discovered notebooks and draft catalogues at the Ashmolean. This would be a logistically complex and time-consuming project for which, despite its undoubted importance, there is no obvious source of funding.

22. See the "Research Notes" section for the entry for the object at $<$ http://objects. prm.ox.ac.uk/pages/PRMUID25910.html>.

\section{REFERENCES}

Ashmolean Museum, 1836. A Catalogue of the Ashmolean Museum Descriptive of the Zoological Specimens, Antiquities, Coins, and Miscellaneous Curiosities. Oxford.

Beddie, M.K., 1970. Bibliography of Captain James Cook R.N., F.R.S., Circumnavigator. 2nd edition. Sydney: Mitchell Library.

Beechey, Frederick William, 1831. Narrative of a Voyage to the Pacific and Beering's Strait: to Co-operate with the Polar Expeditions: Performed in His Majesty's Ship Blossom, under the Command of Captain F. W. Beechey... in the Years 1825, 26, 27, 28 (2 vols). London: Henry Colburn and Richard Bentley.

Bockstoce, J.R., 1977. Eskimos of Northwest Alaska in the Early Nineteenth Century: Based on the Beechey and Belcher Collections and Records Compiled During the Voyage of H.M.S. Blossom to Northwest Alaska in 1826 and 1827. Edited by T. K. Penniman. Oxford: Pitt Rivers Museum, University of Oxford.

Clunie, Fergus, 2013. Tapua: "Polished ivory shrines" of Tongan gods. Journal of the Polynesian Society 122 (2): 161-210, 211-24.

2014. The Tongan tapua. In A. Herle and L. Carreau, Chiefs \& Governors: Art and Power in Fiji. Cambridge: Museum of Archaeology and Anthropology, University of Cambridge, pp. 23-24.

Coote, Jeremy, 2005. "From the Islands of the South Seas, 1773-4": Peter Gathercole's special exhibition at the Pitt Rivers Museum. Journal of Museum Ethnography 17: 8-31.

2015 [in press]. Africa, the Pacific, and North America. In A. Macgregor (ed.), The Cobbe Cabinet of Curiosities: An Anglo-Irish Countryhouse Museum (The Paul Mellon Centre for Studies in British Art). London: Yale University Press.

Coote, Jeremy, Peter Gathercole and Nicolette Meister (with contributions by Tim Rogers and Frieda Midgley), 2000. "Curiosities sent to Oxford": The original documentation of the Forster collection at the Pitt Rivers Museum. Journal of the History of Collections 7 (2): 177-92.

Coote, Jeremy, Chantal Knowles, Nicolette Meister and Alison Petch, 1999. Computerizing the Forster ("Cook"), Arawe, and founding collections at the Pitt Rivers Museum. Pacific Arts 19/20: 48-80 
Coote, Jeremy, and Jeremy Uden, 2013. The rediscovery of a Society Islands tamau, or headdress of human hair, in the "Cook-voyage" Forster Collection at the Pitt Rivers Museum - and a possible provenance. Journal of the Polynesian Society 122 (3): 233-55.

Ellis, William, 1829. Polynesian Researches, During a Residence of Nearly Six Years in the South Sea Islands; Including Descriptions of the Natural History and Scenery of the Islands - With Remarks on the History, Mythology, Traditions, Government, Arts, Manners, and Customs of the Inhabitants (2 vols). London: Fisher, Son, \& Jackson.

Gatty, Charles T., 1879-1882. Catalogue of the Mayer Collection (3 vols). London. Hawkesworth, John, 1773. An Account of the Voyages Undertaken by the Order of His Present Majesty for Making Discoveries in the Southern Hemisphere, and Successively Performed by Commodore Byron, Captain Wallis, Captain Carteret, and Captain Cook, in the Dolphin, the Swallow, and the Endeavour. Drawn up from the Journals which were Kept by the Several Commanders, and from the Papers of J. Banks, by J. Hawkesworth (2nd edition. 3 vols). London: W. Strahan and T. Cadell.

Hooper, Steven, 2006. Pacific Encounters: Art \& Divinity in Polynesia, 1760-1860. London: British Museum Press /Wellington, New Zealand: Te Papa Press. 2013. "Supreme among our valuables": Whale teeth tabua, chiefship and power in Eastern Fiji. Journal of the Polynesian Society 122 (2): 103-60, 221-24. 2014. Tabua. In A. Herle and L. Carreau, Chiefs \& Governors: Art and Power in Fiji. Cambridge: Museum of Archaeology and Anthropology, University of Cambridge, pp. 21-22.

Joppien, Rüdiger, and Bernard Smith, 1985. The Voyage of the Endeavour, 1768-1771, with a Descriptive Catalogue of All the Known Original Drawings of Peoples, Places, Artefacts and Events and the Original Engravings Associated with Them, Volume 1 of The Art of Captain Cook's Voyages (3 vols). New Haven and London: Yale University Press, for the Paul Mellon Center for Studies in British Art, in association with the Australian Academy of the Humanities.

Kaeppler, Adrienne L., 1971. Eighteenth-century Tonga: New interpretations of Tongan society and material culture at the time of Captain Cook. Man (n.s.) 6 (2): 204-20. 1972. The use of documents in identifying ethnographic specimens from the voyages of Captain Cook. Journal of Pacific History 7: 195-200.

MacGregor, Arthur, 2000. Manuscript Catalogues of the Early Museum Collections, 1683-1886 (Part I). British Archaeological Reports, International Series 907. Oxford: Archaeopress, in association with the Ashmolean Museum, Oxford.

Ovenell, R.F., 1986. The Ashmolean Museum, 1683-1894. Oxford: Clarendon Press.

Penniman, T.K., 1957. Report of the Curator of the Pitt Rivers Museum (Department of Ethnology) for the Year Ending 31 July 1956, §16 of Sixty-Eighth Annual Report of the Delegates of the University Museum (for the Year Ending 31 July 1956). Oxford University Gazette 87 (no. 2,922, suppl.; 6 March 1957): 652-57.

Petch, Alison, 2007. Opening the Pitt Rivers Museum. Journal of Museum Ethnography 19: 101-12. 
Richards, Rhys, 2012. The Austral Islands: History, Art and Art History. Paremata: Paremata Press.

Rowell, George Augustus and John Henry Parker, 1879. The Assistant Keepership and the New Catalogue of the Ashmolean Museum. [Correspondence.] Oxford: Privately printed.

Te Rangi Hiroa (Peter H. Buck), 1944. Arts and Crafts of the Cook Islands. Bernice P. Bishop Museum Bulletin 179. Honolulu: Bernice P. Bishop Museum.

Whitby n.d., [2012]. Fish and Ships! Food on the Voyages of Captain CookCatalogue to the Exhibitions 2011-2012 in the Captain Cook Memorial Museum, Whitby. Whitby: Captain Cook Memorial Museum.

Wood, J.G., 1868. Australia, New Zealand, Polynesia, America, Asia and Ancient Europe, Vol. 2 of his The Natural History of Man: Being an Account of the Manners and Customs of the Uncivilized Races of Men (2 vols). London: George Routledge \& Sons.

\section{ABSTRACT}

In a recent account, in the Journal of the Polynesian Society, of Tongan tapua"polished ivory shrines"-Fergus Clunie refers to an example in the University of Oxford's Pitt Rivers Museum as being "tenuously provenanced" to Cook's voyages. A detailed discussion of the tapua's documentation is provided to demonstrate how this "tenuous" provenance has no basis in fact, before other possible histories are considered.

Keywords: Tonga, tapua, whale teeth, museum collections, documentation.

\section{CITATION AND AUTHOR CONTACT DETAILS}

Coote, ${ }^{1}$ Jeremy, 2014. A Tongan Tapua in the Pitt Rivers Museum: Historiographical Notes and Curatorial Reflections. Journal of the Polynesian Society 123 (4): 399-420. DOI: $10.15286 /$ jps. 123.4.399-420

${ }^{1}$ Corresponding author: Pitt Rivers Museum, South Parks Road, Oxford OX1 3PP, United Kingdom. E-mail: jeremy.coote@prm.ox.ac.uk 